Open access e-Journal

Earth Science India, eISSN: $0974-8350$

Vol. 8 (I), January, 2015, pp. 1-14

http://www.earthscienceindia.info/

\title{
Climate Change in South Asian Countries
}

\author{
Nandita D. Ganguly \\ Department of Physics \\ St Xavier’s College, Ahmedabad 380 009, India
}

\begin{abstract}
Almost all the South Asian countries are at present vulnerable to climate change and are affected with several climate related hazards, the frequency and intensity of which are likely to increase in future. Temperature and rainfall extremes may have severe impact on agriculture and health. In the light of these observations, this paper is aimed at investigating the changes in temperature and rainfall patterns over the period from 19012012 at four south Asian countries, namely India, Bangladesh, Sri Lanka and Maldives and the present status of agricultural and health in changing climate.
\end{abstract}

Keywords: South Asian countries; precipitation; potential evapotranspiration; temperature; wet day frequency; droughts; agriculture; health

\section{Introduction}

Rising temperature and uncertainties of rainfall in South Asian countries has been the subject of major concern in recent years, as it may destroy the existing ecosystem and exert adverse effects on human health and vegetation (Huq et al., 1998; Ali, 1999). Eleven out of the 12 years, between 1995 and 2006 were among the 12 warmest years since 1850. Deficient rainfall and rising temperatures have enhanced evapotranspiration and drying resulting in more regions experiencing droughts (IPCC, 2007). While very little increase was observed in the surface air temperature of different Indian regions during the period from 1901 to 1997, and some regions even showed a declining trend in temperature (Kumar and Hingane, 1988; Kumar et al., 1994; Ganguly and Iyer, 2009), a significant increase was observed from 1998 onwards, which became all the more pronounced in 2009 (Ganguly, 2011). Annual and monsoon rainfall decreased, but pre-monsoon, post-monsoon and winter rainfall increased over a period of 135 years (1871-2005) in India (Vijay Kumar et al., 2010). A study by the Intergovernmental Panel on Climate Change concluded that, although the climate-related disasters are not increasing in number, they have become more stronger, thereby increasing the susceptibility of these regions to potential losses (IPCC, 2007), which are likely to reverberate across nation boundaries in an era of globalization (Statistical Yearbook for Asia and the Pacific, 2013).

Monsoon in South Asia can be categorized into two segments namely, South-West Monsoon or the summer monsoon (June to September) and North-East Monsoon or the winter monsoon (October to November), based on the direction of rain bearing winds. SouthWest Monsoon comprises of rain-bearing winds, blowing from the Indian Ocean onto the south Asian landmass, bringing rains to most parts of the subcontinent, while the North east monsoon comprises of relatively dry winds with less moisture blowing from Mongolia and northwestern China, onto the Indian Ocean, bringing rain to limited parts of India, Bangladesh, Maldives and Srilanka. Bangladesh, India, Maldives and Sri Lanka are all 
developing south Asian countries, where the influence of climate variability on agriculture and health is widely recognized and where economic development is severely affected by climate change. Success or failure of crops controls the economic development of these countries. Apart from this, as heavy rainfall and warm temperature provide an ideal habitat for Anopheles mosquitoes, malaria and tuberculosis are two potentially lethal diseases that have greatly affected these countries. Thus changing temperature and rainfall trends play a crucial role in the economy and health of these countries. Although a number of studies have been carried out to determine the temperature and rainfall trends in each of these countries over different time periods, very few studies are available, which study the trends simultaneously over all these four countries at an annual and decadal scale. In the light of these observations, the changes in temperature and rainfall patterns have been examined simultaneously at these four countries over the period from 1901 - 2012 and their possible influence on agriculture and health have been explored.

\section{The Study Area}

India lies to the north of the equator between $6^{\circ} \mathrm{N}$ and $36^{\circ} \mathrm{N}$ latitude and $68^{\circ} \mathrm{E}$ and $97^{\circ} \mathrm{E}$ longitudes. It is difficult to generalize the climate of India, which comprises a wide range of weather conditions across varied topography and a large geographical area. Bangladesh is located between latitudes $20^{\circ} \mathrm{N}$ to $26^{\circ} \mathrm{N}$ and longitudes $88^{\circ} \mathrm{E}$ to $92^{\circ} \mathrm{E}$. It is bordered on the west, north and east by India, on the south-east by Myanmar, and on the south by the Bay of Bengal. It has a hot, humid, tropical climate, influenced primarily by monsoon and partly by pre-monsoon and post-monsoon circulations. Most part of the country is low-lying. Maldives, located at the equator, is the smallest country of Asia in terms of population and area and is also Earth's lowest country with an average 1.5 meters elevation above sea level. It is an archipelago of 26 low lying coral atolls located in the Indian Ocean. It has two distinct seasons; dry season (northeast monsoon) extending from January to March and wet season (southwest monsoon) from mid-May to November. Sri Lanka lies in the Indian Ocean, southwest of the Bay of Bengal, between latitudes $5^{\circ}$ and $10^{\circ} \mathrm{N}$, and longitudes $79^{\circ}$ and $82^{\circ} \mathrm{E}$. It is separated from the Indian subcontinent by the Gulf of Mannar and Palk Strait. It experiences a tropical and warm climate.

\section{Data and Processing}

The linear trend of climate variables (precipitation, potential evapotranspiration, maximum temperature, minimum temperature and wet day frequency) has been examined over a period of 111 years from 1901-2012 at these four south Asian countries using East Anglia University, U.K. Climatic Research Unit's (CRU) updated gridded climate dataset (CRU TS3.10) obtained from monthly observations at meteorological stations across these countries. The CRU dataset consists of country averages at a monthly, seasonal and annual frequency. Spatial averages are calculated using area-weighted means. Station anomalies were interpolated into $0.5^{\circ}$ latitude/longitude grid cells, and combined with an existing climatology to obtain absolute monthly values. The dataset compares very favorably, with the major deviations mostly in regions and/or time periods with sparser observational data and does not have any missing data over land. The data set includes diagnostics associated with each interpolated value that indicates the number of stations used in the interpolation, allowing determination of the reliability of values in an objective way (Harris et al., 2014). 
Open access e-Journal

Earth Science India, eISSN: $0974-8350$

Vol. 8 (I), January, 2015, pp. 1-14

http://www.earthscienceindia.info/

The Indian regional annual rainfall data set has been obtained from the website of Indian Institute of Tropical Meteorology (IITM), Pune. The network of rain-gauge stations selected provides at least one representative station per district having a reliable record for the longest possible period. The network selected under these constraints consists of uniformly distributed stations for which rainfall data are available for about 90 percent of the total area of the country.

The annual rainfall data set over the period from 1948 - 2010 for fifteen districts of Bangladesh namely; Rangpur, Dinajpur, Jessore, Faridpur, Ishurdi, Dhaka, Comilla, Rajshahi, Barisal, Chittagong, Bogra, Khulna, Mymensingh, Chandpur and Sylhet was obtained from the website of Bangladesh Agricultural Research Council(BARC).

\section{Results and Discussion}

\section{Long term annual trend:}

Both, the maximum and minimum surface air temperatures indicate a significant increasing linear trend of $0.0099^{\circ} \mathrm{C} / \mathrm{yr}$ and $0.0092^{\circ} \mathrm{C} / \mathrm{yr}$ respectively at Srilanka followed by $0.007^{0} \mathrm{C} / \mathrm{yr}$ and $0.008^{0} \mathrm{C} / \mathrm{yr}$ respectively at India, $0.007^{0} \mathrm{C} / \mathrm{yr}$ and $0.0068^{0} \mathrm{C} / \mathrm{yr}$ respectively at Maldives and $0.0056{ }^{0} \mathrm{C} / \mathrm{yr}$ and $0.0048{ }^{0} \mathrm{C} / \mathrm{yr}$ respectively at Bangladesh. The observed increase in temperature may be due to the influence of local factors, such as a sharp population growth accompanied by uncontrolled urbanization and rapid industrialization, resulting in high levels of pollution and imbalances in the regional climate as suggested by Singh et al. (2005) and Ganguly (2011) in India. It is further observed that unlike maximum and minimum temperature, the annual precipitation and number of rain days in a year do not exhibit a clear and consistent linear trend at these four countries. While annual precipitation indicates a small decreasing trend $(-0.0958 \mathrm{~mm} /$ year and $-0.702 \mathrm{~mm} /$ year $)$, the number of rain days in a year indicates an increasing trend (0.0204 days/year and 0.038 days/year) at India and Bangladesh respectively, resulting in a decrease in net intensity of rainfall. The linear trend of annual precipitation as well as the number of rain days in a year at Sri Lanka indicate an increasing trend $(0.385 \mathrm{~mm} /$ year and 0.0842 days/year respectively), while they indicate a decreasing trend (-0.4024 mm/year and -0.0284 days/year respectively) at Maldives (Fig. 1).

\section{Decadal trend:}

In order to ascertain whether the climate of these countries is changing monotonically in a single direction, the entire CRU data set was further grouped into eleven decades (19011910; 1911-1920; 1921 - 1930; 1931 - 1940; 1941 - 1950; 1951 - 1960; 1961 - 1970; 1971 1980; 1981 - 1990; 1991 - 2000; 2001 - 2010) and the linear trend of precipitation, rain days, potential evapotranspiration, maximum and minimum temperature were examined for different decades. Both, the maximum and minimum temperature at all these countries exhibited a negative (cooling) trend ranging between $-0.5^{0} \mathrm{C} /$ decade to $-0.004^{0} \mathrm{C} /$ decade and $-0.0612^{0} \mathrm{C} /$ decade to $-0.012^{0} \mathrm{C} /$ decade respectively from 1901 up to around 1970 and a positive (warming) trend ranging between $0.03^{0} \mathrm{C} /$ decade to $0.104^{0} \mathrm{C} /$ decade and $0.005^{0} \mathrm{C} /$ decade to $0.129{ }^{\circ} \mathrm{C} /$ decade respectively thereafter. Overall precipitation at India, Srilanka and Bangladesh indicate a small positive trend in the last three decades. 

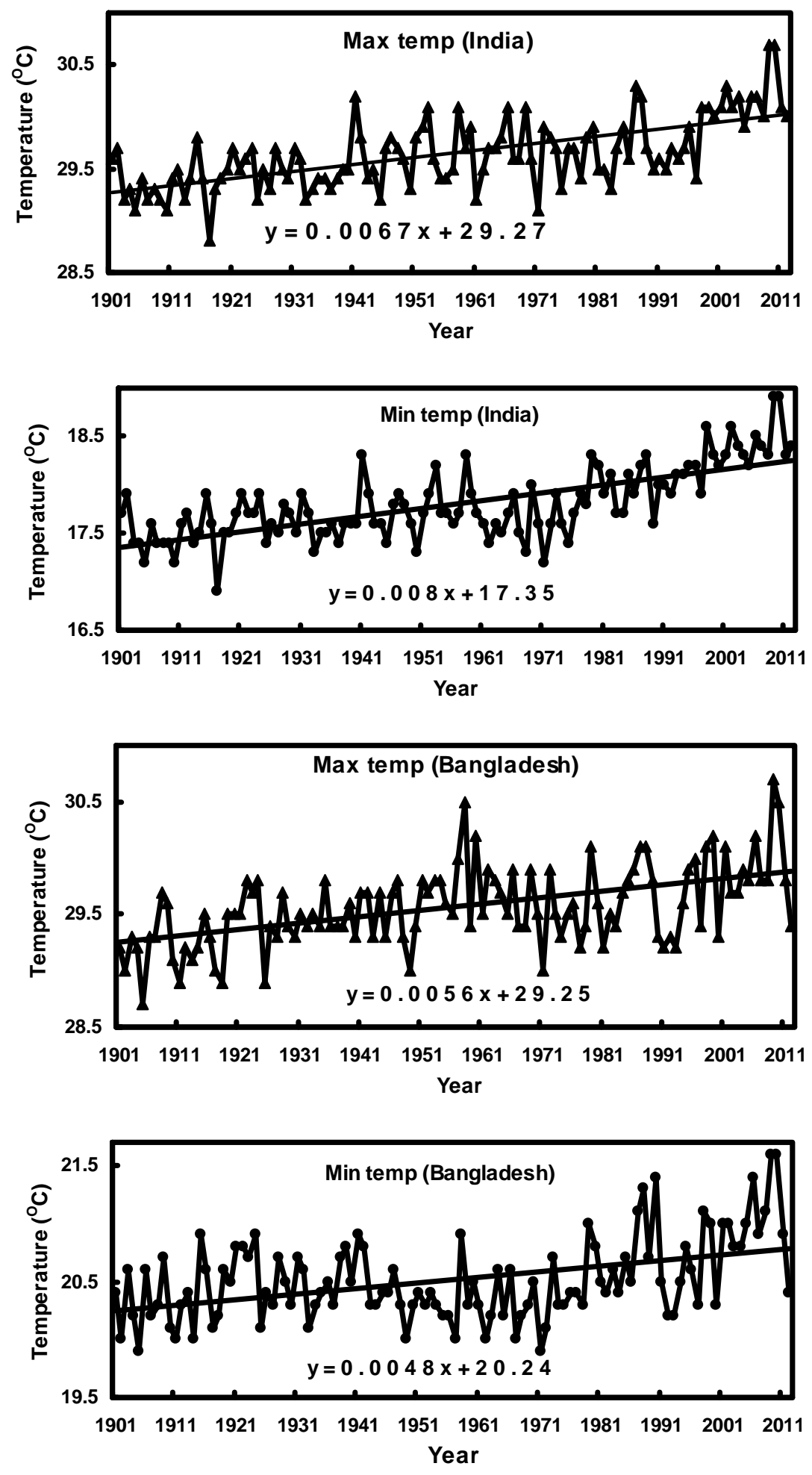
Open access e-Journal

Earth Science India, eISSN: $0974-8350$

Vol. 8 (I), January, 2015, pp. 1-14

http://www.earthscienceindia.info/
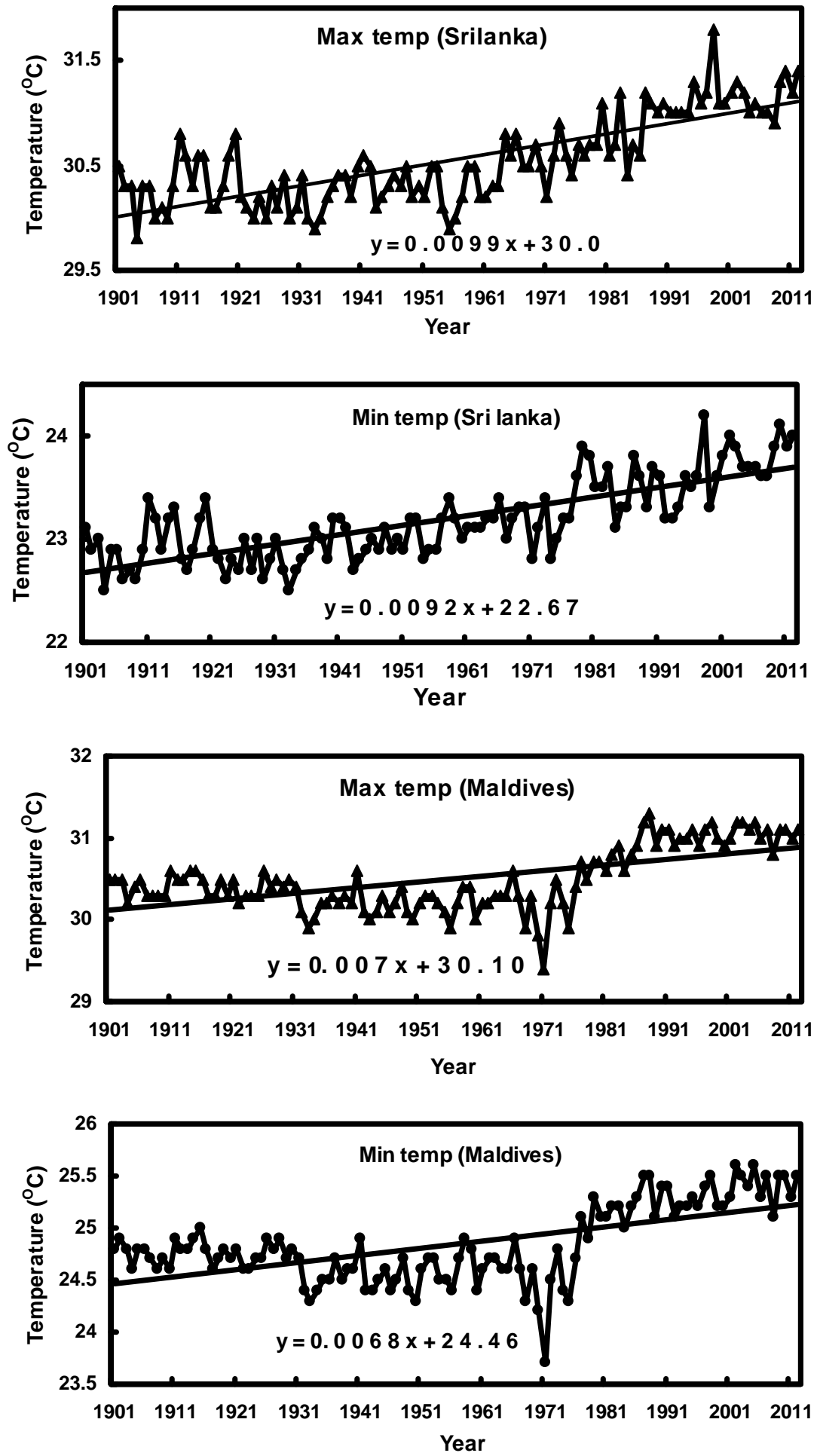

Fig. 1: Time series of maximum and minimum temperature observed in India, Bangladesh, Srilanka and Maldives (source of data: CRU) 


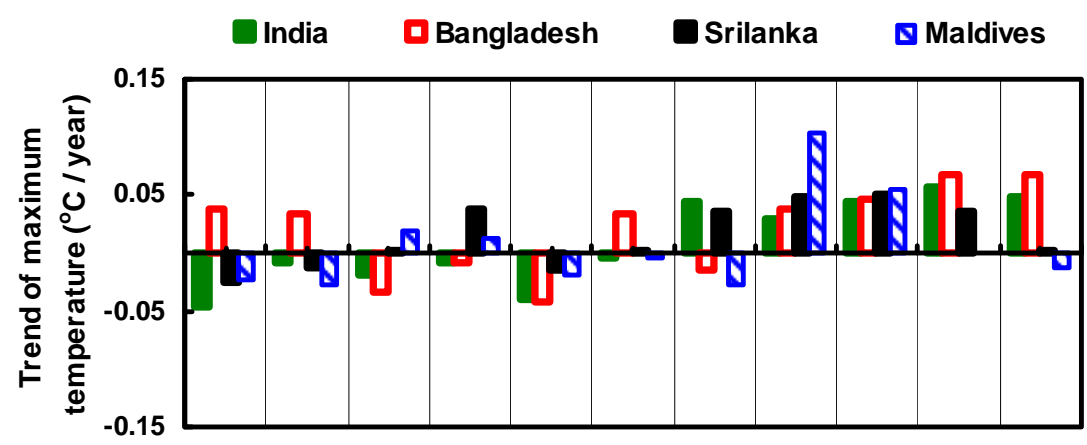

1901- 1911- 1921- 1931- 1941- 1951- 1961- 1971- 1981- 1991- 2001$\begin{array}{lllllllllll}1910 & 1920 & 1930 & 1940 & 1950 & 1960 & 1970 & 1980 & 1990 & 2000 & 2010\end{array}$ Decade
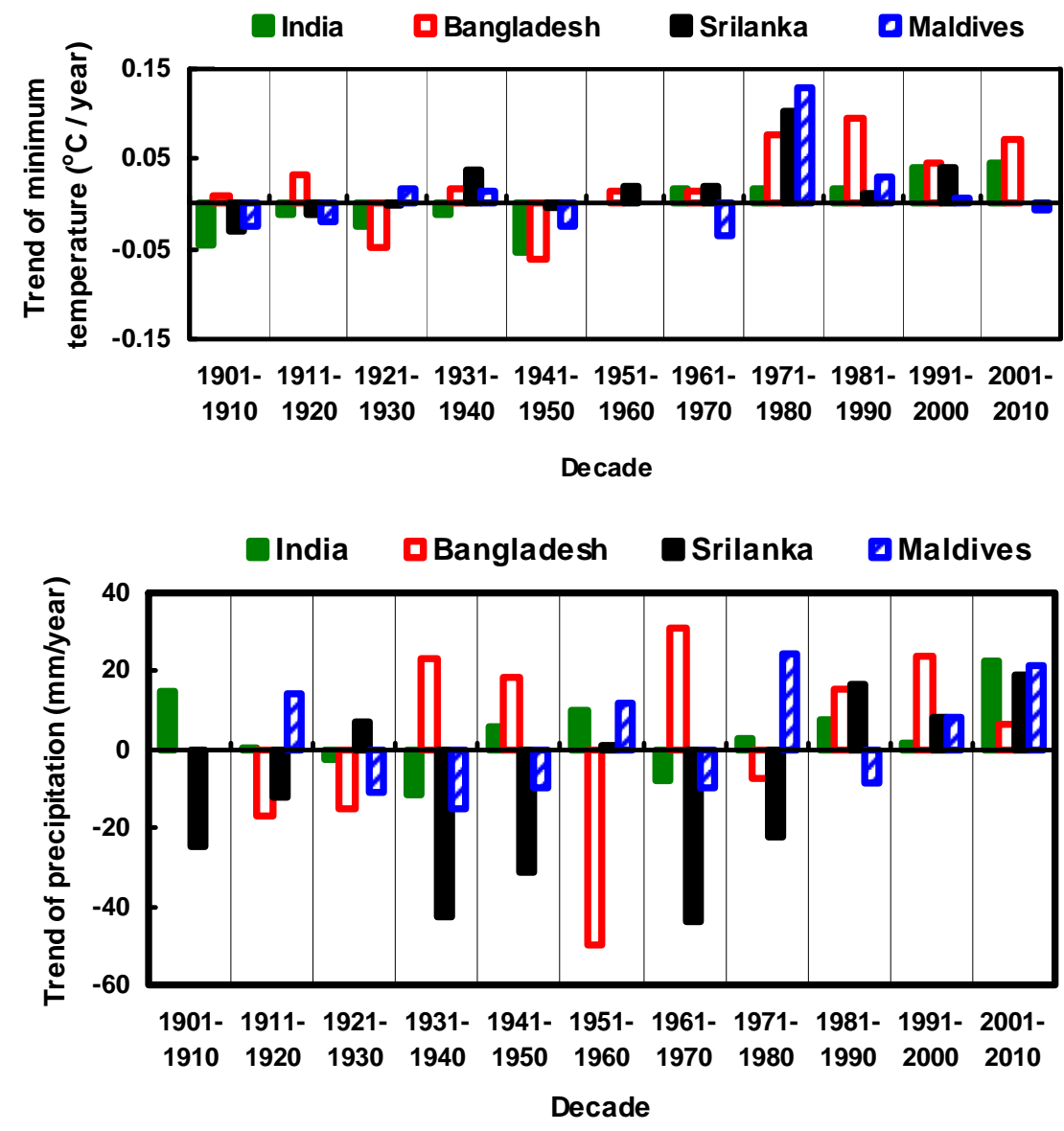
Open access e-Journal

Earth Science India, eISSN: $0974-8350$

Vol. 8 (I), January, 2015, pp. 1-14

http://www.earthscienceindia.info/
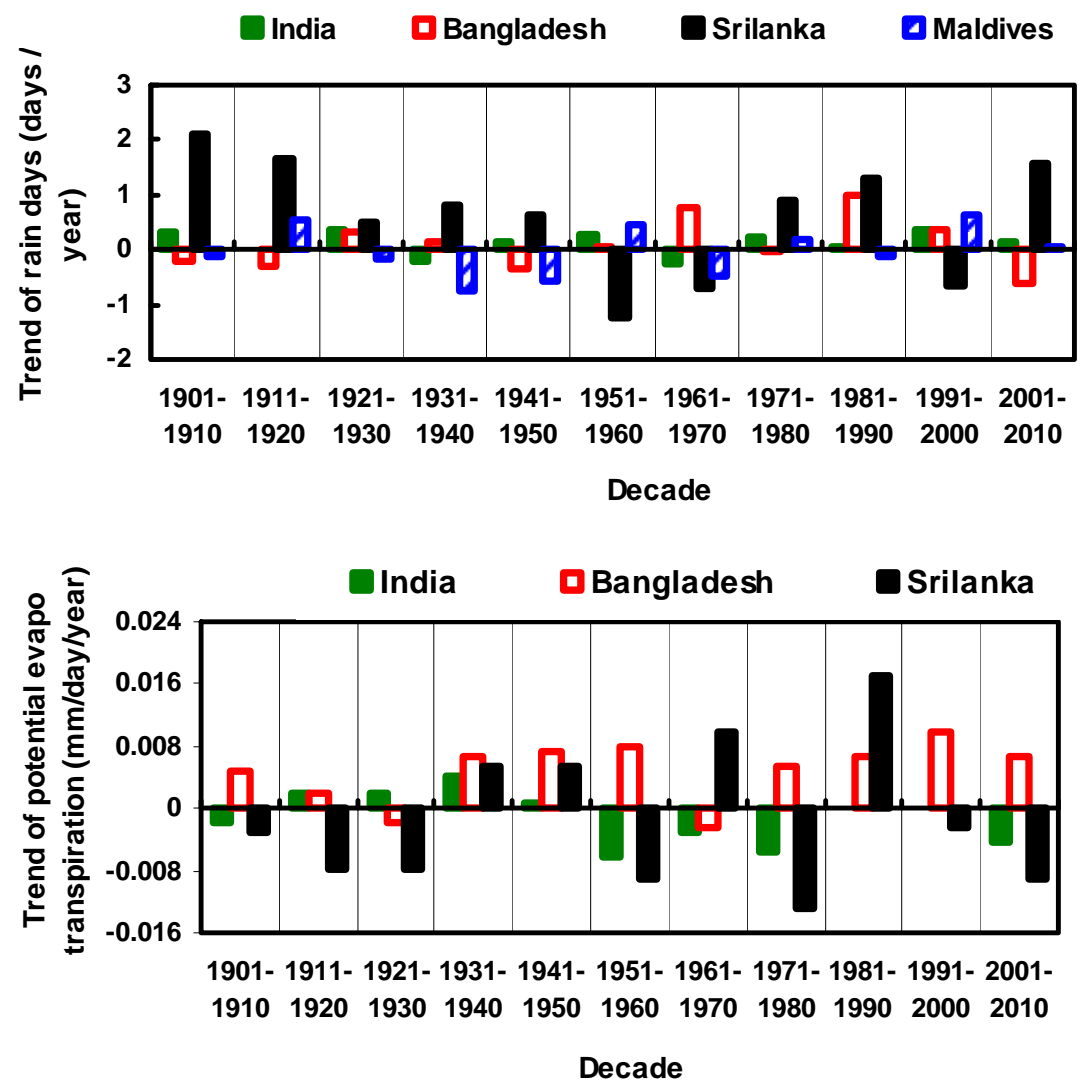

Fig. 2: Decadal trend of maximum temperature, minimum temperature, precipitation, rain days and potential evapotranspiration (source of data: CRU)

However, surprisingly, potential evapotranspiration decreased in India and Srilanka during the last few decades although the temperatures (both max and min), have increased, while it increased at Bangladesh as expected (Fig. 2). This may be because, apart from temperature, there are several factors affecting evapotranspiration such as relative humidity, wind speed, moisture available in a plant's soil and the type of plant involved in the transpiration process. As temperature, moisture available in a plant's soil and wind speed increase, transpiration also increases, while as the relative humidity increases, transpiration decreases. Moreover, different plants transpire water at different rates. Thus a decrease in potential evapotranspiration at India and Srilanka in spite of increasing temperatures may indicate an increase in humidity levels, decrease in moisture available in a plant's soil and wind speed or a change in soil texture and type of vegetation during the last three decades. However, since systematic measurements of humidity levels, moisture available in a plant's soil, wind speed, soil texture and type of vegetation at India and Srilanka could not be obtained, it is difficult to conclude strongly on the mechanism leading to the observed decrease in potential evapotranspiration. 


\section{Frequency of above and below average precipitation:}

The entire precipitation dataset for each country was divided into three sections. The years for which the precipitation was within $\pm 10 \%$ of the long term (1901-2012) average were considered as normal precipitation years, while those with $<10 \%$ and $>10 \%$ of the long term (1901-2012) average were termed as below normal and above normal precipitation years respectively (www.nrsc.gov.in). Thereafter, the entire precipitation dataset for each country was grouped into eleven decades and the frequency of occurrence of below and above average precipitation was examined for these four countries (Fig. 3). It was observed that the frequency of below average precipitation was higher during the decades 1901 - 1910 and 1991 - 2010 in India; 1901 - 1910, 1971 - 1980 and 2001 - 2010 at Bangladesh; 1901 - 1920 and 1971 - 2000 at Srilanka and 1931 - 1940, 1981 - 1990 at Maldives. The frequency of above average precipitation was higher during the decades 1931 - 1940 and 1951 - 1990 in India; 1911 - 1920, 1941 - 1960 and 1981 - 1990 at Bangladesh; 1921 - 1950, 1961 - 1970 and 2001 - 2010 at Srilanka and 1971 - 1980 at Maldives. Although relationship between El Niño and deficient rainfall are well established in Indonesia, Australia, and the tropical Pacific islands (Mooley and Parthasarathy, 1983), it is observed that not all El Niño years correspond to below average precipitation in these four countries. Precipitation in these countries is highly unpredictable and varies significantly from one decade to another, ranging from long dry spells of below average precipitation and drought, to periods of above normal precipitation. Also, the decadal changes observed in below or above average precipitation are different for these countries, although they lie in close proximity to each other. However, on the whole, below average precipitation has increased in all these countries in the recent decades.

In view of the decreasing precipitation and increase in the number of rain days, the occurrence of drought was examined for these four countries. According to the India Meteorological Department (IMD), meteorological drought occurs, when the seasonal rainfall received over an area is less than $75 \%$ of its long-term average value. Meteorological drought is further classified as moderate drought if the rainfall is between $50 \%-75 \%$ of its longterm average value and severe drought when the rainfall is less than $50 \%$ of its long-term average value (www.nrsc.gov.in).

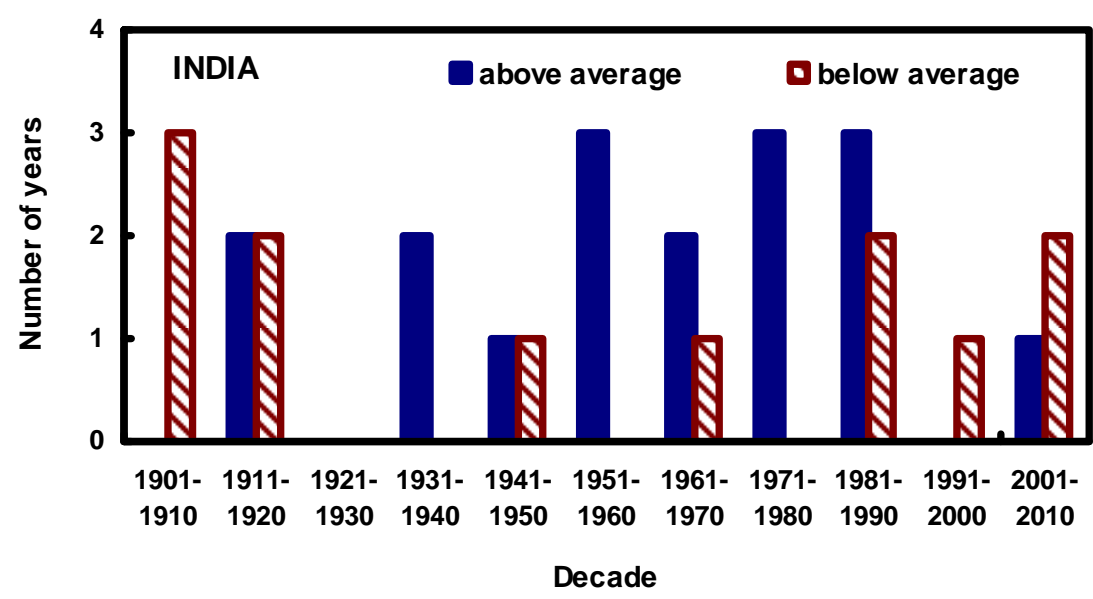


Open access e-Journal

Earth Science India, eISSN: $0974-8350$

Vol. 8 (I), January, 2015, pp. 1-14

http://www.earthscienceindia.info/
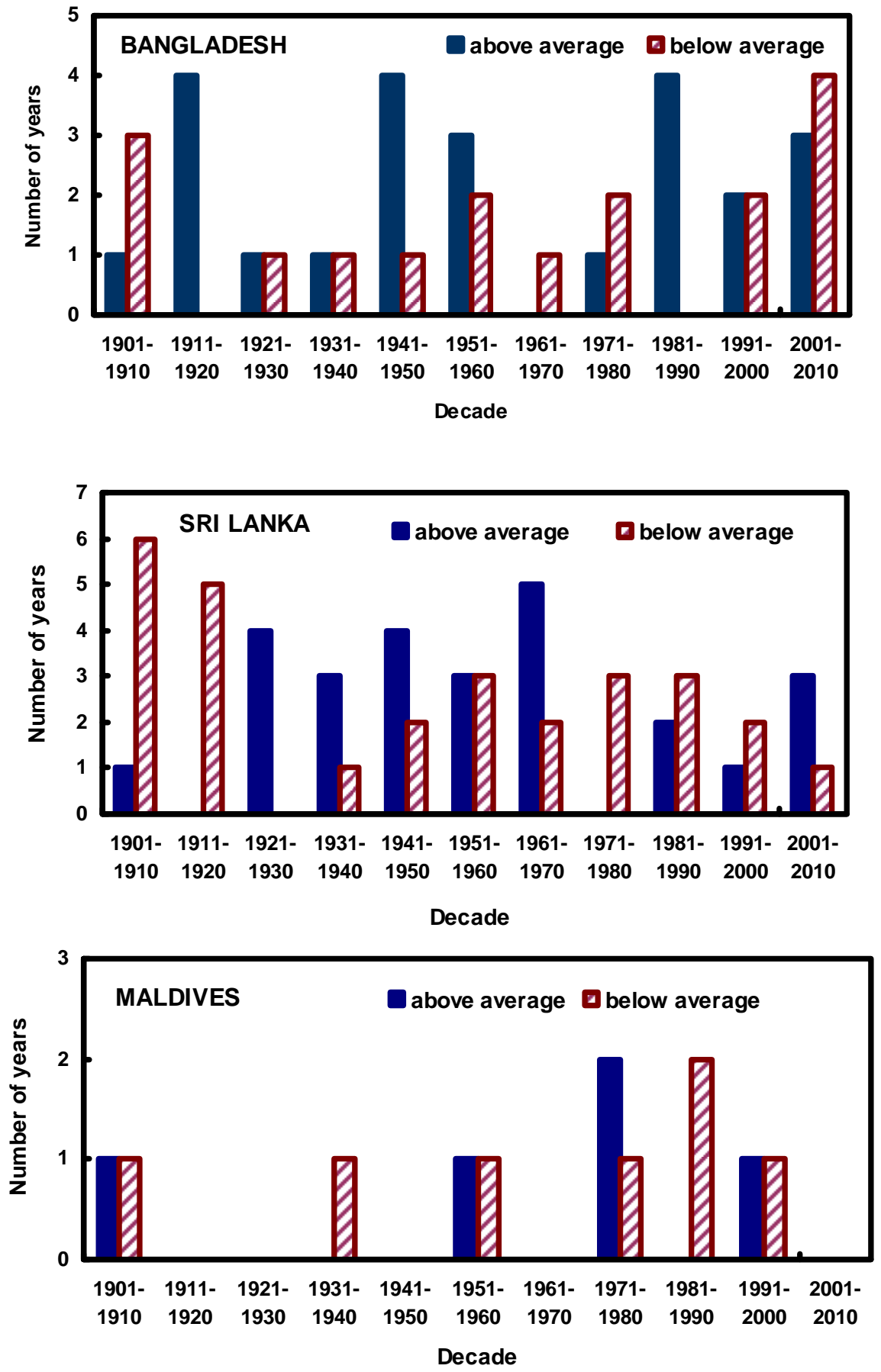

Fig. 3: Frequency of above and below average precipitation years observed in India, Bangladesh, Sri Lanka and Maldives (Source of Data: CRU) 
It is observed from CRU data set, that moderate droughts have occurred during 1908, 1916, 1950, 1952, 1968, 1974, 1980, 1983 and 1987 in Sri Lanka while no droughts have occurred in Maldives. However, unlike Srilanka and Maldives, India and Bangladesh comprise of a wide range of weather condition spanning across varied topology and large geographical area, due to which generalizing the rainfall over the entire country may not give a very authentic result. Therefore using the IITM data set, which sub divides entire India into five homogeneous regions as shown in Fig. 4 [North West (NW), Central North West (CNW), Peninsula (IP), North East (NE), Central North East (CNE) and Hilly regions (data not available)], the frequency of occurrence of drought was examined over the period from 1901 - 2012. Similarly, using the data obtained from the website of Bangladesh Agricultural Research Council (http://www.barc.gov.bd), the frequency of occurrence of drought was examined over the period from 1948 - 2010 for fifteen districts namely; Rangpur, Dinajpur, Jessore, Faridpur, Ishurdi, Dhaka, Comilla, Rajshahi, Barisal, Chittagong, Bogra, Khulna, Mymensingh, Chandpur and Sylhet in Bangladesh. It is observed that North West region of India is highly prone to both moderate and severe droughts; while the remaining parts of India are prone to only moderate droughts. A major part of Bangladesh is observed to be drought porn. Moderate drought prone areas are mainly located in the Northern, NorthWestern, Central, Southern and South eastern regions of Bangladesh spread over the districts of Rangpur, Dinajpur, Jessore, Faridpur, Ishurdi, Dhaka, Comilla, Rajshahi, Barisal, Chittagong and Bogra while severe drought prone areas are mainly located in the Central and Southern regions of Bangladesh spread over the districts of Khulna, Mymensingh, Chandpur. The eastern regions including districts like Sylhet do not experience any drought. Case studies of the North West region of India and Mymensingh district of Bangladesh are shown in Fig. 4.

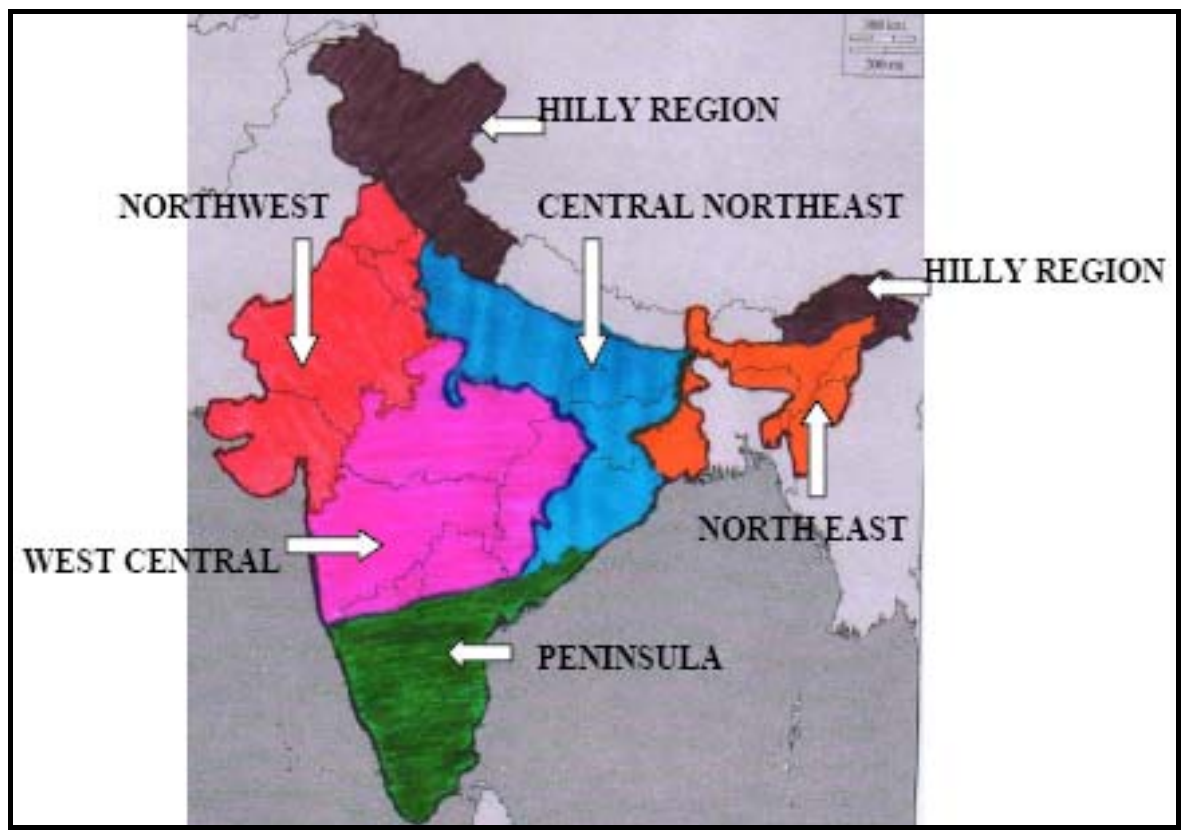


Open access e-Journal

Earth Science India, eISSN: $0974-8350$

Vol. 8 (I), January, 2015, pp. 1-14

http://www.earthscienceindia.info/
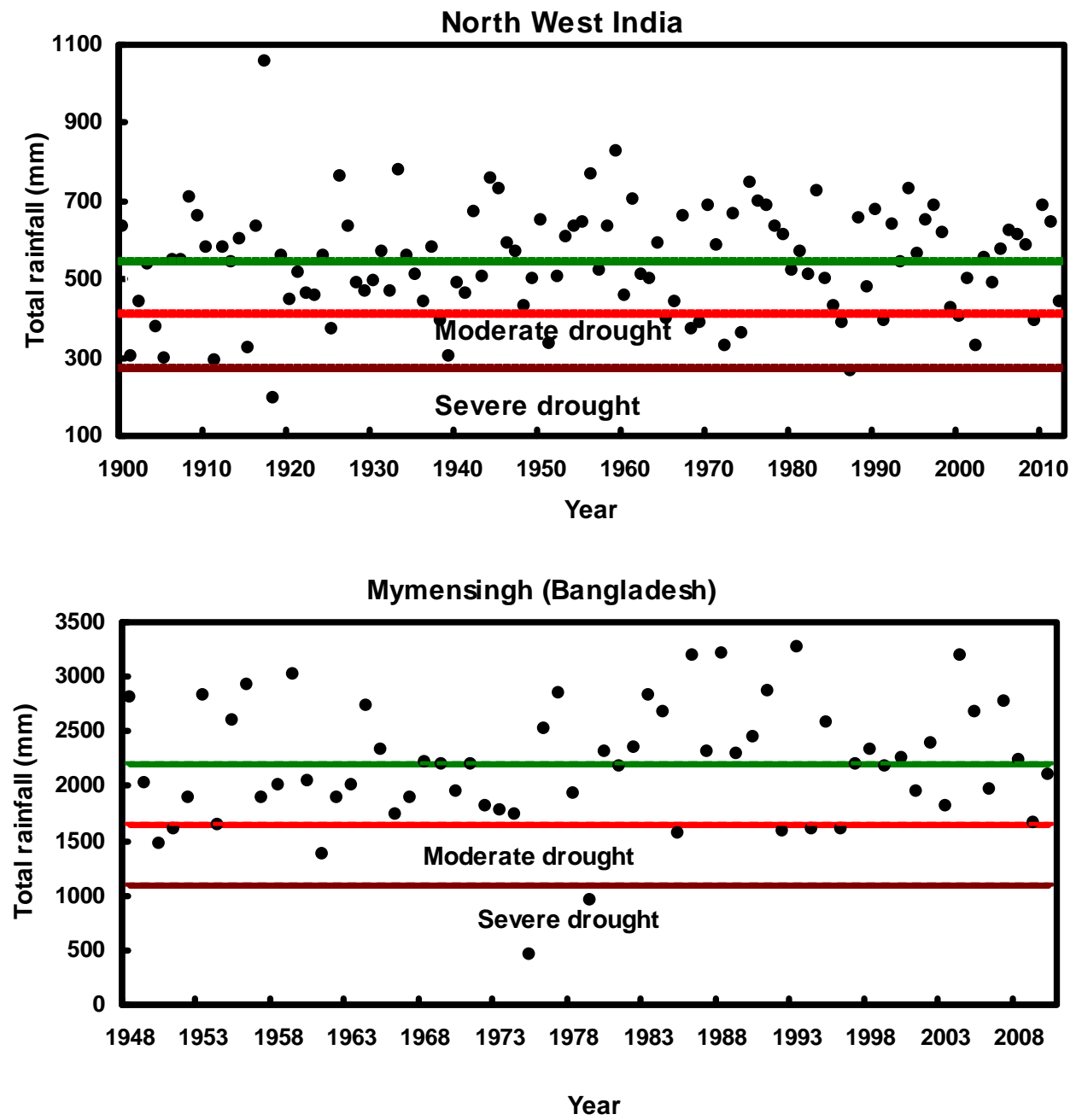

Fig. 4: Map of homogenous regions of India and droughts observed in the North West region of India and Mymensingh district of Bangladesh (Source of Data: IITM and BARC)

\section{Status of agriculture and health in changing climate:}

As changes in temperature and rainfall can affect agriculture yields and health adversely; the present status of cereal yield, and reported cases of diseases such as malaria and tuberculosis was explored.

It is observed that cereal yield has increased significantly for all countries in the recent years (Fig. 5). Positive steps taken by these countries to mitigate the risks arising from rising temperature and the uncertainties of rainfall might have resulted in lowering agricultural losses. 

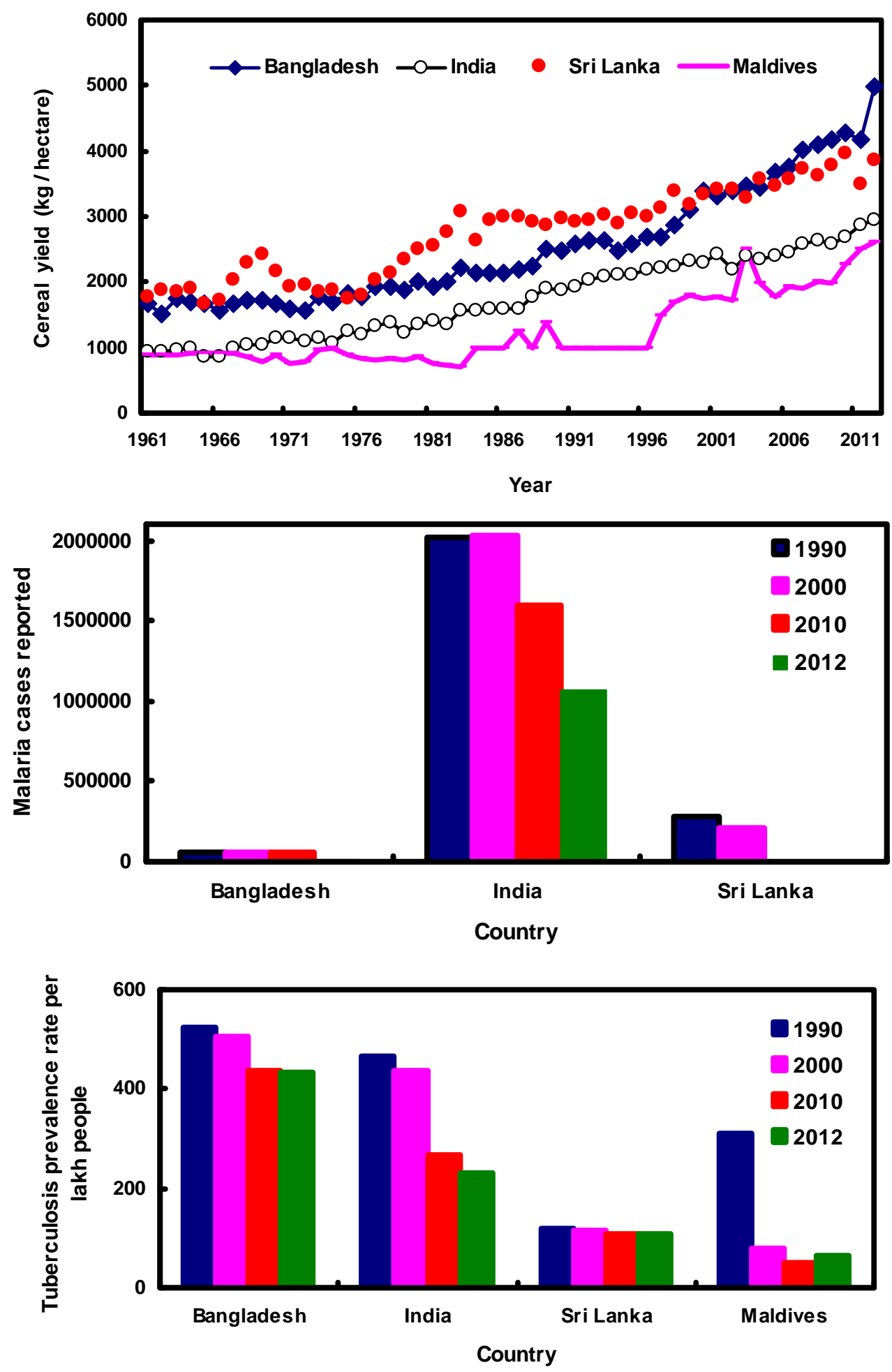

Fig. 5: Observed cereal yield, reported malaria cases and tuberculosis prevalence rate per lakh people (Source of data: World Bank). 
Open access e-Journal

Earth Science India, eISSN: $0974-8350$

Vol. 8 (I), January, 2015, pp. 1-14

http://www.earthscienceindia.info/

The combination of high temperature and precipitation in tropical and subtropical Asian countries present an ideal habitat for Anopheles mosquitoes resulting in the spread of malaria. These conditions are also favorable for the spread of infectious diseases such as tuberculosis (World Malaria Report 2012). It is observed that although the number of reported malaria and tuberculosis cases is still high, their numbers have decreased significantly in recent years (Fig. 5). Improvements in detection, treatment and surveillance might have proven to be instrumental in reducing malaria deaths. However, as the causes of outbreaks of infectious disease are quite complex and do not have a simple relationship with change in temperature or rainfall; it is difficult to conclude strongly on the magnitude of health risk that will result from climate change in the coming years.

\section{Conclusion}

The changes in temperature and rainfall patterns has been examined at four south Asian countries, namely India, Bangladesh, Sri Lanka and Maldives, over the period from 1901-2012. It is observed that the overall maximum and minimum temperatures have increased over this period. Precipitation in these countries is highly unpredictable and varies significantly from one decade to another. Potential evapotranspiration has decreased in India and Srilanka during the last few decades, while it has increased at Bangladesh.

The number of reported malaria and tuberculosis cases has decreased while cereal yield has increased significantly in recent years. It is concluded that the positive steps taken by these countries to mitigate the risks arising from rising temperature and the uncertainties of rainfall, might have resulted in lowering human, agricultural and economic losses.

Acknowledgments: The author acknowledges her gratitude to the honorable reviewers for their valuable suggestions. The climate variables have been obtained from Climatic Research Unit (CRU) dataset produced in 2013 at the University of East Anglia (Harris et al., 2014). The Indian regional annual mean rainfall data set has been obtained from the website of Indian Institute of Tropical Meteorology (IITM), Pune. Rainfall data for Bangladesh has been obtained from the website of Bangladesh Agricultural Research Council. Data for malaria, tuberculosis and cereal yield have been obtained from the website of World Bank.

\section{References}

Ali, A. (1999) Climate change impacts and adaptation assessment in Bangladesh. Climate Res., v.12, pp. 109116.

IPCC (2007) Climate Change 2007: The physical science basis. Solomon, S., Quin, D., Manning, M., Chen, X., Marquis, M., Averyt, K.B., Tignor, H. L., Miller, M. (eds.) Contribution of Working Group I to the Fourth Assessment Report of the Intergovernmental Panel on Climate Change. Cambridge University Press, Cambridge, 996p.

Kumar, K.R. and Hingane, L.S. (1988) Long-term variations of surface air temperature at major industrial cities of India. Climate Change, v.13, pp. 287-307.

Kumar, K. R., Kumar, K.K. and Pant, G.B. (1994) Diurnal asymmetry of surface temperature trends over India. Geophysical Research Letters, v. 21, pp. 677-680.

Ganguly, N. D. and Iyer, K.N. (2009) Long-term variations of surface air temperature during summer in India. International Journal of Climatology, v. 29, pp. 735-746.

Ganguly, Nandita D. (2011) Investigating the possible causes of climate change in India with satellite measurements. International Journal of Remote Sensing, v. 32 (3), pp. 687 - 700.

Vijay Kumar, Sharad K. Jain, and Yatveer Singh (2010) Analysis of long-term rainfall trends in India. Hydrological Sciences Journal, v. 55(4), pp. 484-496. 
Huq, S., Karim, Z., Asaduzzaman, M. and Mahtab, F. (1998) Vulnerability and adaptation to climate change for Bangladesh. Kluwer Academic Publishers, Dordrecht, 135p.

Statistical Yearbook for Asia and the Pacific (2013) F. Environment, pp. 231-236 (Date assessed: 25 April 2014)

Harris, I., Jones, P. D., Osborn, T. J. and Lister, D. H. (2014) Updated high-resolution grids of monthly climatic observations - the CRU TS3.10 dataset. International Journal of Climatology, v. 34(3), pp. 623-642.

Singh, R. P., Prasad, R. K., Chauhan, S. S. and Singh, S. (2005) Impact of growing urbanization and air pollution on the regional climate over India. International Association for Urban Climate Newsletter, v. 14 , pp. $5-10$

Mooley, D. A., and Parthasarathy, B. (1983) Indian summer monsoon and El Nino. Pure and Applied Geophysics, v. 121 (2), pp. 339-352.

World Malaria Report 2012 (www.who.int/malaria/publications/world_malaria report_2012) (Date assessed: 20 April 2014)

(Received:1.9.2014; Accepted: 12.1.2015) 